\title{
Neuromuscular blocking drugs in anaesthesia
}

\begin{abstract}
Monitoring the neuromuscular junction
Neuromuscular blocking drugs (NMBD's) are used widely in anaesthesia to facilitate intubation, to dccrease anaesthetic requirements and to provide relaxation and immobility during surgery. The effect of these drugs must either wear off or be antagonized to ensure adequate respiratory function and airway maintenance after surgery. The margin of safety of the neuromuscular junction is high: relaxation is not achieved unless a large number of receptors is occupied. ${ }^{1}$ Also, it may be difficult to reverse the NMBD's unless some neuromuscular activity is present. ${ }^{2}$ Furthermore, there are wide individual variations in drug requirement. Thus, neuromuscular monitoring is necessary for controlled anaesthetic practice.
\end{abstract}

\section{Clinical assessment}

After anaesthesia, the degree of residual paralysis can be estimated by the ability of the patient to sustain head lift or hand grip. When respiratory function is assessed the system needs to be stressed because tidal volumes may be preserved cespite severe weakness. ${ }^{3-5}$ Vital capacity, inspiratory force and maximal voluntary ventilation are more sensitive but depend on patient co-operation and may be influence by pain, narcotics or poor motivation. Similarly, the clinical indicators of inadequate paralysis during anaesthesia, such as movement, respirator triggering and change in inflation pressure, occur only during light anaesthesia. Thus, the absence of these signs does not ensure adequate relaxation.

\section{Neuromuscular monitoring}

The need for monitoring which is specific to the effect of NMBD's is clear and can be achieved by the use of stimulators which deliver an electrical shock near a nerve. The response of the corresponding muscle is determined exclusively by the degree of neuromuscular blockade
Francois Donati MD PHD, Joan C. Bevan MD FFARCS, David R. Bevan MB FFARCS

\section{STIMULUS FREQUENCY}

1 Single stimulus (SS). The simplest mode of stimulation is the delivery of single shocks separated by long intervals, $>10 \mathrm{~s}$, and observing the twitch response. This mode has two disadvantages: a control, pre-relaxant twitch is necessary ${ }^{6}$ and the presence of a full response does not guarantee full neuromuscular tecovery.

2 Tetanic stimulation (TET). Non-depolarizing block is characterized by fade in response to repetitive stimulation. ${ }^{6,7}$ High frequencies of stimulation, $200 \mathrm{~Hz}$, are more sensitive in the detection of residual neuromuscular blockade than lower frequencies, $30-100 \mathrm{~Hz}$. However, TET is limited by the post-tetanic facilitation which results in overestimation of neuromuscular activity with further testing. High frequency TET, $100-200 \mathrm{~Hz}$, produces fade in the presence of enflurane and isoflurane even in the absence of NMBD's. Also, TET cannot be used in the conscious patient because it is painful.

3 Train-of-four stimulation (TOF). The ideal mode of stimulation would involve a small number of impulses to minimize post-tetanic facilitation at a frequency low enough for the observer to appreciate the response but high enough for fade to be present. Fade appears, with non-depolarizing block, at frequencies greater than $0.1 \mathrm{~Hz}$ and is constant in the range $2-50 \mathrm{~Hz}^{7}$ At $2 \mathrm{~Hz}$, maximum fade is reached by the fourth impulse. ${ }^{6}$ Therefore train-offour stimulation (TOF), consisting of four impulses

Departments of Anaesthesia, Royal Victoria Hospital, Montreal Children`s Huspital, and McGill University, Montreal, Quebec

Address correspondence so: Dr. D.R. Bevan, Department of Anaesthesia, Royal Victoria Hospital, 687 Pine Avenue West, Montreal, Que, H3A IA]. 
TABLE J Advantages and disadvantages of different stimulating patterns

\begin{tabular}{|c|c|c|c|}
\hline Pattern & Frequency & Advantages & Disadvantages \\
\hline $\begin{array}{l}\text { Single twitch } \\
\text { (SS) }\end{array}$ & $<0.1 \mathrm{~Hz}$ & $\begin{array}{l}\text { Tcchnicaily casy } \\
\text { Can be uscd in awake paticnts } \\
\text { Can be repeated after } 10 \text { seconds }\end{array}$ & $\begin{array}{l}\text { Needs control } \\
\text { Insensitive } \\
\text { Cannot scparate depolarizing from } \\
\quad \text { non-depolarizing }\end{array}$ \\
\hline $\begin{array}{l}\text { Tetanus } \\
\text { (TET) }\end{array}$ & $30-200 \mathrm{~Hz}$ repeat at $2-5$ minutes & $\begin{array}{l}\text { Distinguishes nom-depolarizing } \\
\text { Sensitive }\end{array}$ & $\begin{array}{l}\text { Painful } \\
\text { Modifies non-depolarizing block } \\
\text { Fade with inhajation agents }\end{array}$ \\
\hline $\begin{array}{l}\text { Train-of-four } \\
\text { (TOF) }\end{array}$ & $2 \mathrm{~Hz}$ repeat at 12 seconds & $\begin{array}{l}\text { Differentiates non-depolarizing block } \\
\text { Control unnecessary } \\
\text { More sensitive than SS } \\
\text { Can be used in awake patients } \\
\text { Can be repeated after } 10 \text { seconds }\end{array}$ & \\
\hline
\end{tabular}

at a frequency of $2 \mathrm{~Hz}$ applied at intervals greater than $10 \mathrm{~s}$, has emerged as the ideal compromise. ${ }^{8}$ Its sensitivity is similar to TET at $30-50 \mathrm{~Hz}$.

TOF has several advantages over SS (Table I). Firstly, the degree of non-depolarizing block can be estimated by relating the height of the fourth twitch in each train to the height of the first so that control, pre-paralysis measurements are unnecessary. The fourth twitch usually disappears when the first is $75-80$ per cent blocked although differences may exist between NMBD's. Secondly, TOF fade identifies the onset of phase II succinylcholine block and, finally, TOF fade is a more sensitive indicator of residual blockade than SS. A]though the site of action of NMBD's may not be confined to a single receptor, ${ }^{9}$ the concept of receptor occupancy has been useful in establishing the sensitivity to different modes of stimulation (Table II).

WHICH NERVE TO STIMULATE?

Theoretically, any superficial nerve supplying one or more muscles can be used for monitoring. In practice, the ulnar is stimulated most commonly and is the standard for correlation with respiratory weakness. It can be stimulated either at the wrist or elbow. The median, facial and peroneal nerves are also suitable although the results may not be identical.

\section{STIMULATOR CHARACTERISTICS}

The stimulator should be capable of delivening 200-400 volt electrical impulses of $0.1-0.2 \mathrm{~ms}$ duration at a frequency of $2 \mathrm{~Hz}$. The ability to supply SS anc TET at $50-100 \mathrm{~Hz}$ is a desirable feature. Some stimulators are designed to deliver a certain current, instead of a specified voltage, and others, while delivering a set voltage, will display the current supplied. Because a nerve responds to current, not voltage, these features make stimulators more reliable so that improper application of the electrodes or disconnection can be recognized quickly. Needle electrodes are unnecessary if the

TABLE II Comparisons of different modes of stimulation when used with non-depolarizing NMBD's

\begin{tabular}{|c|c|c|c|c|}
\hline \multirow[b]{2}{*}{ Mode } & \multirow{2}{*}{$\begin{array}{l}\text { Receptor } \\
\text { occupancy }\end{array}$} & \multicolumn{2}{|l|}{ Requiremenrs for } & \multirow{2}{*}{$\begin{array}{l}\text { Interval } \\
\text { between tests }\end{array}$} \\
\hline & & Paralysis & Recovery & \\
\hline SS & $75-80$ & Twitch $<10-20 \%$ & Twitch $=100 \%$ & $10 s$ \\
\hline TOF & $70-75$ & Twitch count $<4$ & TOF ratio $>0.7$ & $10 \mathrm{~s}$ \\
\hline Tetanus $30 \mathrm{~Hz}$ for 5 secs & $75-80$ & Maximum fade & No fade & $2-5$ mins $^{2}$ \\
\hline Tetanus $100 \mathrm{~Hz}$ for $5 \mathrm{secs}$ & 50 & Maximum fade & $?^{1}$ & $2-5 \operatorname{mins}^{2}$ \\
\hline Tetanus $200 \mathrm{~Hz}$ for 5 secs & 30 & Maximum fade & $?^{?}$ & $2-5 \operatorname{mins}^{2}$ \\
\hline
\end{tabular}

'Some fade is compatible with adequate neuromuscular recovery.

${ }^{2}$ Estimated. 


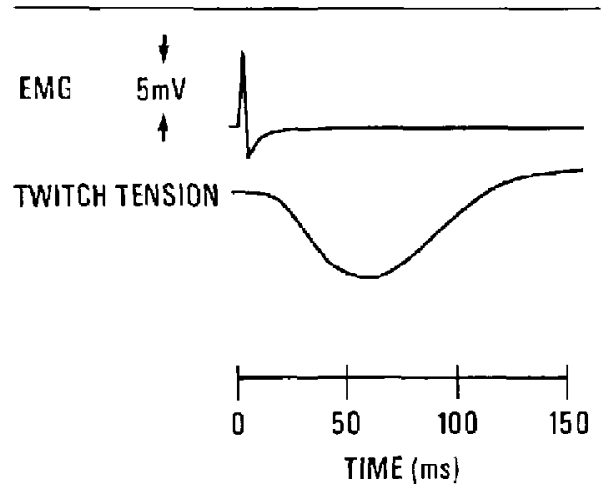

FIGURE 1 Time course of normal emg and corresponding twitch tension.

stimulator can provide sufficient voltage. One silver-silver chloride ECG electrode should be placed over the nerve and the position of the other electrode is not critical.

\section{MEASUREMENT OF RESPONSE}

1 Muscle twitch. In evaluating the muscle response, force transducers are accurate ${ }^{10}$ but cumbersome and their use limited to research. In clinical practice, the observation of TOF fade is simpler but crude. Touch is more sensitive than sight but considerable fade, $>50$ per cent, may be present without detection even by a trained observer. Fade of TET is detected more easily but its use should be limited to situations when no TOF fade can be demonstrated.

2 Electromyography. When the muscle end-plate is depolarized by the action of acetylcholine an action potential spreads along the length of the muscle cell and triggers the contractile process. When a whole nerve trunk is stimulated, an action potential is generated in each of the muscle cells it supplies, unless some degree of neuromuscular block exists (Figure 1). The algebraic sum of all these action potentials can be recorded by electrodes at the surface of the muscle as an electromyogram (EMG). The situation is analogous to the generation of an ECG signal which occurs during the simultaneous depolarization of all cardiac cells. As with the ECG, the largest signal is obtained when electrodes are placed parallel to the axis of depolarization. Since action potentials travel from the neuromuscular junction to both ends of the cell, the best EMG signal is obtained by placing one electrode over the belly with a second near the insertion of the muscle and an indifferent electrode close by. The muscles used most commonly are the adductor digiti quinti and the first dorsal interosseous $^{11,12}$ which are both supplied by the ulnar nerve. The amplitude of the EMG signal is larger $(5-20 \mathrm{mV})$ than the QRS complex of the ECG $(1-3 \mathrm{mV})$ and its duration is shorter $(5-10 \mathrm{~ms}$ vs $80 \mathrm{~ms}$ ). The EMG signal must be amplified before measurement is made of either the peak amplitude, peak-to-peak amplitude or the area under the curve (integrated and rectified signal).

3 Relation between twitch and EMG. There is sufficient similarity between muscle twitch and EMG to consider them equivalent in the clinical setting when using either depolarizing or nondepolarizing relaxants. Electrical recordings require more instrumentation and take longer to set up. Equipment for EMG recording is now available which allows more accurate and less subjective measurements to be made and which can be used on muscles inaccessible to the anaesthetist's eye or hand. ${ }^{13}$

4 Variability of response. There is considerable variation in the sensitivity of different muscles to NMBD's whether EMG or twitch is measured. ${ }^{14}$ The adductor pollicis muscle, supplied by the ulnar nerve, is usually more sensitive than the muscles supplied by the facial nerve and diaphragm. The upper airway musculature and eye muscles are also very sensitive. Consequently, the total disappearance of twitch activity at the adductor pollicis muscle does not guarantee perfect intubating conditions. Conversely, good recovery of insensitive muscles such as those supplied by the facial nerve, does not ensure full neuromuscular recovery.

Stimulation with TOF, applied no more often than every $10 \mathrm{~s}$, has proved to be a very useful guide in the management of muscle relaxation during anaesthesia and in the administration of its antagonists. However, TOF monitoring is no substitute for examination of the patient. No level of TOF recovery is an absolute guarantee that the patient will breathe and maintain an adequate airway. 


\section{Muscle relaxants in children - are they different?}

Although NMBD's were first used in children in 1943 by Cullen, ${ }^{15}$ they were given infrequently until popularized by Jackson-Rees a decade later. ${ }^{16}$ Rapidly, it became clear that, using clinical criteria, the neonate and infant seemed to be sensitive to the non-depolarizing but resistant to the depolarizing relaxants. Much of the evidence is contradictory reflecting the difficulty of accurate measurement of neuromuscular activity and the serious consequences of residual paralysis in the very young. There seems to be agreement that, on a weight for weight basis, the small child is resistant to succinylcholinc. However, recent studies have challenged the traditional belief that they are sensitive to non-depolarizing relaxants.

Physiological background

Anatomical and physiological changes occur during childhood which might modify the response of the small child to NMBD's. The volume of the extracellular fluid, which is the principal volume for distribution of these ionized, water soluble compounds, decreases from 44 per cent of body weight at birth to 22 per cent at one year. The circulation time, which will affect the time of onset of action, is reduced in infiants. Also, the growth of muscle mass increases from 22 per cent of body weight at birth to 38 per cent by adolescence.

MATURATION OF THE NEUROMUSCUI AR JINACTION The neuromuscular system is inmature at birth and its rapid early development is reflected by the acquisition of motor skills in predictable sequence. Structurally, the junction is incomplete until two years and repetitive nerve stimulation is associated with a slow rate of acetylcholine release for the first three months in animals. ${ }^{17}$ Skeletal muscle also undergoes histochemical changes: the proportion of type I fibres (slow-twitch, high oxidative) to type II (fast-twitch, low oxidative) increases in the respiratory muscles from mid-gestation until infancy. At birth the intercostal muscles contain 46 per cent of type I fibres which increase to 65 per cent by two months, whilst the diaphragm contains 25 per cent type I at birth reaching adult values, 65 per cent, at eight months. These adaptations are associated with a greater oxidative capacity and an increased resistance to fatigue. The intrinsic muscles of the hand show a reverse progression from type I to type II. ${ }^{18}$

Neuromuscular transmission is different in infants. In the newborn, the height of the action potential is lower than in the adult. Twitch height is sustained in response to low frequency repetitive stimulation but fade, accompanied by post tetanic facilitation and exhaustion, follows TET. The response to SS, TET and TOF change at one to three months, suggesting that maturation of neuromuscular transmission occurs at this time. 19,20

Some of the confusion concerning the use of NMBD's in small children is beginning to disappear. Current reappraisal of the established drugs and examination of recently introduced compounds, depend upon the use of TOF monitoring with standardized anaesthetic techniques, and the development of micro-assays for pharmacokinetic studies.

\section{Depolarizing relaxants}

\section{SUCCINYLCHOLINE}

Intravenous: The dose required to produce apnoea in neonates is, on a mg $\mathrm{kg}^{-1}$ basis, two to four times greater than in adults 21 (Table III). However, no differences were found in potency or duration of

TABLE III Comparison of neuromucular block and recovery time (mean values) after intravenous succinylcholine 0.5 and $1.0 \mathrm{mig} \cdot \mathrm{kg}^{-1}$ at different ages

\begin{tabular}{|c|c|c|c|c|c|}
\hline \multirow[b]{2}{*}{ Source } & \multirow[b]{2}{*}{ Age } & \multicolumn{2}{|l|}{$0.5 \mathrm{mg} \cdot \mathrm{kg}^{-1}$} & \multicolumn{2}{|l|}{$1.0 \mathrm{mg} \cdot \mathrm{kg}^{-1}$} \\
\hline & & $\begin{array}{l}\text { Max depression } \\
(\%)\end{array}$ & $\begin{array}{l}90 \% \text { recovery } \\
\text { (min) }\end{array}$ & $\begin{array}{l}\text { Max. depression } \\
\text { (\%) }\end{array}$ & $\begin{array}{l}\text { gos recoven } \\
\text { (mill) }\end{array}$ \\
\hline Walts \& Dillon ${ }^{24}$ (1967) & Adults & 100 & 7.4 & 100 & 12.1 \\
\hline Katz \& Ryan ${ }^{25}$ (1969) & Adults & 100 & 10.1 & 100 & 14.6 \\
\hline \multirow{2}{*}{ Cook \& Fischer 23 (1975) } & Children & 83.6 & 3.0 & 100 & 4.8 \\
\hline & Infants & 69.0 & 2.3 & 85.3 & 4.0 \\
\hline
\end{tabular}


TABLE IV Comparison of neuromuscular block (ranges) and onset and recovery timcs (mean values) after intramuscular succinylcholine $4 \mathrm{mg} \cdot \mathrm{kg}^{-1}$ at different ages

\begin{tabular}{lllll}
\hline Source & Age & $\begin{array}{l}\text { Max. depression } \\
(\text { G) }\end{array}$ & $\begin{array}{l}\text { Time so max. } \\
\text { depression (min) }\end{array}$ & $\begin{array}{l}\text { Time co full } \\
\text { recovery (min) }\end{array}$ \\
\hline Walts \& Dillon ${ }^{24}(1967)$ & Adults & 100 & 1.8 & 30 \\
Liu er al ${ }^{28}(1981)$ & Children & $85-100$ & 3.5 & 21.5 \\
Suthetland et al. ${ }^{27}(1983)$ & Infants & $20-100$ & 4.0 & 15.6 \\
\hline
\end{tabular}

action when doses were compared on the basis of surlace area. ${ }^{22}$ Cook and Fisher ${ }^{23}$ demonstrated, using SS, that succinylcholine given intravenously in a dose of $\mathrm{l} \mathrm{mg} \cdot \mathrm{kg}^{-1}$ to infants, aged one to ten weeks, produced blockade equal to that produced by $0.5 \mathrm{mg} \cdot \mathrm{kg}^{-1}$ in older children. At these equipotent doses the recovery times were similat in the two groups. Again, when dosage was calculated on a surface area basis there was a linear relationship between the log dose and potency and duration of action in infants and children. Subsequently, they showed that the sensitivity to succinylcholine of neonates aged one to ten days was similar to infants. ${ }^{26}$

Intramuscular: Intramuscular administration of succinylcholine provides an alternative route of administration but its usefulness in emergency situations requiring rapid intubation is limited unless predictable relaxation can be obtained quickly. In a dose of $4 \mathrm{mg} \cdot \mathrm{kg}^{-1}$ twitch depression of 80-90 per cent was produced in infants ${ }^{27}$ and older children $^{28}$ but only after a delay of about four minutes which is slower than in adults (Table IV). The recovery times in both studies were similar; 15-20 minutes. It was anticipated that the increased ECF volume in the infants would decre'dse the potency and duration of action of succinylcholine. However, the onset characteristics may have been concealed by the infant's increased cardiac output and decreased circulation time and the duration of action prolonged by his decreased plasma cholinesterase activity. ${ }^{29}$ In both studies TOF monitoring revealed the presence of phase II block, TOF ratio $<0.5$, but this was not associated with delayed recovery. Three cases of pulmonary oedema have been described following intramuscular succinyl choline in infants. ${ }^{30}$ The mechanism is unclear and it is uncertain whether its relationship to succinylcholine is causal or coincidental. However, the incidence of arrhythmias, particularly bradycardia, is reduced after intramuscular administration.
Infusion: When succinylcholine is given by continuous infusion to children over one year old, it was noticed that phase II block occurred after about $4 \mathrm{mg} \cdot \mathrm{kg}^{-1}$ and that this was associated with tachyphylaxis $^{31}$ which is similar to observations in adults. Goudsouzian and Liu vbserved that the succinylcholine requirement in a few infants aged less than three months seemed to be greatly increased but that phase II block did not occur until a dose of about $6 \mathrm{mg} \cdot \mathrm{kg}^{-1}$ has been given. ${ }^{32}$ Thus, the maintenance of stable neuromuscular blockade with a succinylcholine infusion requires close monitoring of the neuromuscular junction with frequent aiteration in the dose of succinylcholine.

\section{Non-depolarizing relaxants}

The lack of adequate data has not hindered firm recommendations for the use of curare-like drugs in paediatric anaesthesia. Neuromuscular monitoring is difficult in small babies whose arms may be smaller than the transducers used in measurement. In addition, surgery in neonates may be performed in the acutely ill with severe cardiorespiratory, neurological or congenital disease. Consequently, the absorption, distribution and clinical effects of the NMBD's are likely to be erratic and unpredictable. Nevertheless, it is difficult to condone comparisons of studies which use different anaesthetic techniques and different nerve stimulation fre quencies, which extrapolate dose response curves beyond the data points, which use historical controls, in which onset and recovery data are derived disregarding the use of equipotent doses, and when transatlantic differences in response are ignored. Too much of the data in children is derived from subjects more than one year old after maturation of the neuromuscular junction and when ECF volume approaches adult levels. Only recently have these criticisms and the false conclusions which they support been appreciated so that studies with the newer relaxants, atracurium and vecuronium, are more reliable than those for the established agents. 
TABLE V Comparison of potency of non-depolarizing relaxants in adults and children

\begin{tabular}{|c|c|c|c|c|c|c|}
\hline & Source & Amaesthesia & \multicolumn{2}{|c|}{ Monitoring } & $\begin{array}{l}E D_{50} \\
m g \cdot k g^{-1}\end{array}$ & $\begin{array}{l}E D_{9 s} \\
m g \cdot \mathrm{kg}^{-1}\end{array}$ \\
\hline \multicolumn{7}{|l|}{ Atrackrium } \\
\hline Adults & Basta ${ }^{182^{33}}$ & $\mathrm{~N}_{2} \mathrm{O}-\mathrm{O}_{2}$ - fentanyl & \multicolumn{2}{|c|}{ TOF $0.1 \mathrm{~Hz}$} & 0.11 & 0.2 \\
\hline Adolescents (11-17) & Goudsouzian. '83 & $\mathrm{N}_{2} \mathrm{O}-\mathrm{O}_{2}$-halothane & \multicolumn{2}{|c|}{ TOF $0.1 \mathrm{~Hz}$} & 0.12 & 0.18 \\
\hline Children $(2-10)$ & Goudsouzian $83^{34}$ & $\mathrm{~N}_{2} \mathrm{O}-\mathrm{O}_{2}$-halothane & \multicolumn{2}{|c|}{ TOF $0.1 \mathrm{~Hz}$} & 0.11 & 0.17 \\
\hline Infants & Goudsouzian ' $84^{35}$ & $\mathrm{~N}_{2} \mathrm{O}-\mathrm{O}_{2}$-halothane & \multicolumn{2}{|c|}{ TOF $0.1 \mathrm{~Hz}$} & 0.11 & 0.17 \\
\hline \multicolumn{7}{|l|}{ Vecuronium } \\
\hline Aduits & Fahey ${ }^{2} 81^{36}$ & $\mathrm{~N}_{2} \mathrm{O}-\mathrm{O}_{2}$-halothane & SS & $0.15 \mathrm{~Hz}$ & 0.015 & 0.03 \\
\hline Children $(1-8)$ & Fisher \& Miller $83^{37}$ & $\mathrm{~N}_{2} \mathrm{O}-\mathrm{O}_{2}$-halothane & SS & $0.15 \mathrm{~Hz}$ & 0.019 & 0.03 \\
\hline Infants $(0-12 / 12)$ & Fisher \& Miller ${ }^{\prime} 83^{37}$ & $\mathrm{~N}_{2} \mathrm{O}-\mathrm{O}_{2}$-halothane & SS & $0.15 \mathrm{~Hz}$ & 0.017 & 0.03 \\
\hline \multicolumn{7}{|l|}{ Pancuronium } \\
\hline Adults & Fahey ' $81^{36}$ & $\mathrm{~N}_{2} \mathrm{O}-\mathrm{O}_{2}$-halothane & SS & $0.15 \mathrm{~Hz}$ & 0.02 & 0.04 \\
\hline Children (5/52-7 years) & Goudsouzian ' $74^{38}$ & $\mathrm{~N}_{2} \mathrm{O}-\mathrm{O}_{2}$-halothane & SS & $0.25 \mathrm{~Hz}$ & 0.03 & 0.05 \\
\hline \multicolumn{7}{|l|}{$\mathrm{dTC}$} \\
\hline Adults & Donlon ' $74^{39}$ & $\mathrm{~N}_{2} \mathrm{O}-\mathrm{O}_{2}$-narcotic & SS & $0.25 \mathrm{~Hz}$ & 0.15 & 0.31 \\
\hline Children (0-7 years) & Goudsouzian ' $78^{40}$ & $\mathrm{~N}_{2} \mathrm{O}-\mathrm{O}_{2}$-halothane & SS & $0.25 \mathrm{~Hz}$ & 0.2 & 0.38 \\
\hline \multicolumn{7}{|l|}{ Metocurine } \\
\hline Adults & Donlun $74^{79}$ & $\mathrm{~N}_{2} \mathrm{O}-\mathrm{O}_{2}$-narcotic & SS & $0.25 \mathrm{~Hz}$ & 0.07 & 0.175 \\
\hline Children (0-7 ycars) & Goudsouzian $78^{41}$ & $\mathrm{~N}_{2} \mathrm{O}-\mathrm{O}_{2}$-halothane & SS & $0.25 \mathrm{~Hz}$ & 0.07 & 0.2 \\
\hline
\end{tabular}

When these results are combined with the careful pharmacokinetic analyses at different ages with d-tubocurarine it is possible to create a framework to predict the behaviour of NMBD's in children. In this review attempts will be made to limit comparisons to studies in which the methodology is similar and preferably to those which originated from the same institution. When this is not possible, the conditions are described.

\section{POTENCY}

Studies with atracurium and vecuronium show clearly that the doses required to produce 50 and 95 per cent neuromuscular blockade ( $E_{50}$ and $\left.E D_{95}\right)$ are similar at all ages (Table V). Comparisons of pancuronium, d-tubocurarine and metocurine also give similar results if limited to those using common techniques.

\section{CLINICAL EFFECT}

Equipotent doses of vecuronium produce more rapid onset of action in infants ${ }^{37}$ which may be the result of increased cardiac output and shorter circulation time. Direct comparisons at all ages are not available for the other agents although there is a suspicion that onset times are more rapid in the very young. Similarly, despite the differences among the studies, there is a suspicion that the rate of recovery of all the non-depolarizing relaxants, execpt atracurium, is slower in infants (Table VI).

\section{PHARMACOKINEIICS}

These results can be explained by the pharmacokinetic comparisons of d-tubocurarine made by Fisher et al. in infants, children and adults. ${ }^{44}$ They showed that the sensitivity of the neuromuscular junction to curare, assessed as the plasma concentration at steady state which produced a 50 per cent block $\left(\mathrm{Cp}_{\mathrm{sss}}\right)$, was increased in neonates and infants. However, this was compensated by an increase in the volume of distribution $\left(\mathrm{VD}_{\mathrm{SS}}\right)$ so that the potency of curare in infants on a weight basis was the same as older children and adults (Table VII). They also found that the elimination half-life, $\mathrm{tl} / 2 \beta$, was increased in neonates and infants so that recovery of neuromuscular activity will occur more slowly.

\section{CONCLUSIONS}

Recent evidence suggests that the potency of non-depolarizing relaxants in the very young is similar to older children and adults. Although the sensitivity of the neuromuscular junction to the relaxants may be increased this is matched by an 
TABLE VI Comparison of onset and duration of action of non-depolarizing relaxants in children and adults

\begin{tabular}{|c|c|c|c|c|c|c|c|c|}
\hline & \multirow[b]{2}{*}{ Source } & \multirow[b]{2}{*}{ Anaesthesia } & \multirow{2}{*}{\multicolumn{2}{|c|}{ Monitoring }} & \multirow{2}{*}{$\begin{array}{l}\text { Dose } \\
m g \cdot \mathrm{kg}^{-1}\end{array}$} & \multirow{2}{*}{$\begin{array}{l}\text { Onser } \\
(\min )\end{array}$} & \multicolumn{2}{|c|}{ Recovery (min) } \\
\hline & & & & & & & $95 \%$ & $25-75 \%$ \\
\hline \multicolumn{9}{|l|}{ Atracurium } \\
\hline Adults & Basta $82^{33}$ & $\mathrm{~N}_{2} \mathrm{O}-\mathrm{O}_{2}$-лагcotic & TOF & $\mathrm{Fo} 0.1 \mathrm{~Hz}$ & 0.4 & 1.7 & 63.5 & 11.4 \\
\hline Adolescents & Goudsouzian $183^{34}$ & $\mathrm{~N}_{2} \mathrm{O}-\mathrm{O}_{2}$-halothane & TOF & $\mathrm{F} 0.1 \mathrm{~Hz}$ & 0.4 & 2.0 & 54.7 & 13.5 \\
\hline Children & Goudsolzian $183^{34}$ & $\mathrm{~N}_{2} \mathrm{O}-\mathrm{O}_{2}$-halothane & TOF & $\mathrm{F} 0.1 \mathrm{~Hz}$ & 0.4 & 2.0 & 58.7 & 14.0 \\
\hline Infants & Goudsouzian $83^{35}$ & $\mathrm{~N}_{2} \mathrm{O}-\mathrm{O}_{2}$-halothane & TOF & $\mathrm{Fa} .1 \mathrm{~Hz}$ & 0.25 & - & 38 & 15 \\
\hline \multicolumn{9}{|l|}{ Vecuroniam } \\
\hline Adults & Fahey $181^{36}$ & $\mathrm{~N}_{2} \mathrm{O}-\mathrm{O}_{2}$-halothane & SS & $0.15 \mathrm{~Hz}$ & 0.07 & 2.9 & $53(90 \%)$ & 13 \\
\hline Children & Fisther \& Miller $83^{37}$ & $\mathrm{~N}_{2} \mathrm{O}-\mathrm{O}_{2}$-halothane & SS & $0.15 \mathrm{~Hz}$ & 0.07 & 2.4 & 35 & 9 \\
\hline Infants & Fisher \& Miller $83^{37}$ & $\mathrm{~N}_{2} \mathrm{O}-\mathrm{O}_{2}$-halothane & SS & $0.15 \mathrm{~Hz}$ & 0.07 & 1.5 & 73 & 20 \\
\hline \multicolumn{9}{|l|}{ Pancuronium } \\
\hline Adults & Fahey $181^{36}$ & $\mathrm{~N}_{2} \mathrm{O}-\mathrm{O}_{2}$-halothane & SS & $0.15 \mathrm{~Hz}$ & 0.1 & 5.3 & $1] 4(90 \%)$ & 35 \\
\hline Children (1-7 years) & Goudsouzian ${ }^{\prime} 81^{42}$ & $\mathrm{~N}_{2} \mathrm{O}-\mathrm{O}_{2}$-narcotic & SS & $0.1 \mathrm{~Hz}$ & 0.13 & 2.5 & $90(25 \%)$ & - \\
\hline \multicolumn{9}{|l|}{$d T C$} \\
\hline Adults & Basta $82^{33}$ & $\mathrm{~N}_{2} \mathrm{O} \cdot \mathrm{O}_{2}$-narcolic & TOF & $50.1 \mathrm{~Hz}$ & 0.5 & 3.9 & 137 & 52 \\
\hline Children (4/12-10 years) & Goudsouzian ' $81^{42}$ & $\mathrm{~N}_{2} \mathrm{O}-\mathrm{O}_{2}$-narcotic & $\mathrm{SS}$ & $0.1 \mathrm{~Hz}$ & 0.8 & 2.5 & $79(25 \%)$ & - \\
\hline \multicolumn{9}{|l|}{ Metocurine } \\
\hline Adults & Savarese $77^{43}$ & $\mathrm{~N}_{2} \mathrm{O}-\mathrm{O}_{2}$-narcolic & SS & $0.15 \mathrm{~Hz}$ & 0.4 & 4.1 & $107(25 \%)$ & 一 \\
\hline Children (3-8 years) & Goudsouzian $181^{42}$ & $\mathrm{~N}_{2} \mathrm{O}-\mathrm{O}_{2}$-narcolie & SS & $0.1 \mathrm{~Hz}$ & 0.5 & 2.5 & $83(25 \%)$ & - \\
\hline
\end{tabular}

equivalent increase in the volume of distribution of the drug. Clinically, one may expect a more rapid onset and slower recovery in the very young as a result of cardiovascular and excretory changes. Nevertheless, the need for NMBD's may be reduced because of the baby's reduced muscle mass. Also, the inherent dangers of residual paralysis are greater in the infant so that neuromuscular blocking drugs should be used judiciously and, at the end of anaesthesia, the assessment of recovery is easier with neuromuscular monitoring.

The reversal of neuromuscular blockade It seems surprising that 20 years after the introduction of curare, it was considered necessary to advocate the advantages of neostigmine for its reversal. ${ }^{45}$ Now, although the non-depolarizing relaxants are antagonized almost always, postoperative respiratory failure as a consequence of inadequate reversal remains a common fear.

\section{THE AIMS OF REVERSAL}

The purpose of antagonizing relaxants is to restore neuromuscular activity promptly with the particular goals of re-establishing spontaneous respiration and ensuring protection of the airway. Thus, confirmation of the adequacy of reversal relies either upon measurements of ventilation or upon tests of neuromuscular activity which have been correlated previously with the ability to support breathing (Table VIII). Decreased inspiratory force can be detected when the TOF ratio is less than $0.7^{46}$ so that

TABLE VII Pharmacokjnetic variables for d-iubocurarine ${ }^{a 4}$

\begin{tabular}{|c|c|c|c|c|c|}
\hline & & $\begin{array}{l}t \frac{1}{2} \beta \\
(\min )\end{array}$ & $\begin{array}{l}V D_{s s} \\
\left(l \cdot k_{g^{-1}}\right)\end{array}$ & $\begin{array}{l}C p . \\
\left(m l+k^{-1}-\min ^{-1}\right)\end{array}$ & $\begin{array}{l}C p_{s s 50} \\
\left(\mu g \cdot m t^{-t}\right)\end{array}$ \\
\hline Neonates & 0-2 months & 174 & 0.74 & 3.7 & 0.18 \\
\hline Infants & 2-12 months & 130 & 0.52 & 3.3 & 0.27 \\
\hline Children & $1-12$ years & 90 & 0.41 & 4.1 & 0.42 \\
\hline Adults & & 89 & 0.3 & 3.0 & 0.53 \\
\hline
\end{tabular}


TABLE VIII Correlation between tests of neuromuscular activity and respiratory function. After Miller ${ }^{4}$

\begin{tabular}{ll}
\hline Respiratony function & Neuromuscular function \\
\hline Normal tidal volumc & Reduced twitch height and sustained tetanus al $30 \mathrm{~Hz}$ \\
Normal expiratory flow and vital capacity & Normal train-of-four \\
Normal inspiratory force & Sustained tetanus at $100 \mathrm{~Hz}$ \\
Nomal hcad lift and hand grip & Sustained tetanus at $200 \mathrm{~Hz}$ \\
\hline
\end{tabular}

NMBD's should be reversed unless there is no fade in the response of the adductor pollicis to TOF stimulation of the ulnar nerve.

\section{CHOICE OF REVERSAL AGENT}

Anticholinesterases: Until recently, neostigmine was the antagonist used most frequently, although it had been suggested that the longer duration of action of pyridostigmine would prevent the occurrence of "recurarization." It is now clear that sustained return of neuromuscular function can be achieved with any of the anticholinesterases; neostigmine, pyridostigmine or edrophonium, if used in adequate dosage ${ }^{47,48}$ The time coursc of their actions is different; edrophonium has the most rapid onset and shortest duration of action whilst the reverse is true of pyridostigmine ${ }^{49,50}$ (Figure 1). Approximate equivalent doses are:

$$
\text { neostigmine } \begin{aligned}
1 \mathrm{mg} & =\text { pyridostigmine } 5 \mathrm{mg} \\
& =\text { edrophonium } 15 \mathrm{mg}
\end{aligned}
$$

Pharmacokinetic studies have demonstrated that edrophonium is cleared only slightly more rapidly from the plasma than neostigmine or pyridostigminc, ${ }^{51}$ and this does not explain why small doses, 2-10 $\mathrm{mg}$, have an evanescent effect when used in patients with myasthenia gravis. Edrophonium has other advantages as an antagonist; it requires half as much atropine to block its muscarinic effect as does neostigmine, ${ }^{50}$ and in animals has less intestinal stimulating capacity. ${ }^{52}$ Miller and Cronnelly ${ }^{53}$ have suggested that the shorter onset and lower atropine requirement justify a preference for edrophonium over neostigmine. However, with small doses of edrophonium, the initial antagonism may not be sustained, at least when measured with TET. ${ }^{54}$ Nevertheless, it seems that for the antagonism of the shorter acting, newer relaxants, atracurium and vecuronium, edrophonium is an ideal agent.
Physostigmine, although an effective anticholinesterase, has no place as an antagonist of neuromuscular blockade because, as a tertiary amine, it crosses the blood-brain barricr rapidly and in doses used to antagonize the central anticholinergic syndrome it did not reverse a curare block.

4-Aminopyridine: Although neostigmine, edrophonium and pyridostigmine may have other actions at the neuromuscular junction, it is usually considered that the antagonism of non-depolarizing blockade occurs mainly as a result of their anticholinesterase activity. Consequently, there is always the possibility that they may induce a depolarizing block if given in the absence of non-depolarizing relaxants or when recovery from the latter is almost complete. ${ }^{55} 4$-Aminopyridine is an antagonist which acts by increasing the release of acetylcholine from the motor nerve terminal. It has no muscarinic effect and has been shown to antagonize the neuromucular block produced by antibiotics as well as that of muscle relaxants. Unfortunately, in man, doses which produce antagonism of neuromuscular blockade are associated with central nervous system excitation, restlessness and confusion. In animals, it caused an increase in heart rate and blood pressure as a result of facilitation of sympathetic transmission. Consequently, it is unlikely to have a place in clinical practice.

Atropine or glycopyrolate? The onset of action of atropine as an antimuscarinic agent is rapid and matches the onset of action of edrophonium better than that of neostigmine. ${ }^{56}$ Thus, heart rate is maintained better with atropine-edrophonium than atropine-neostigmine mixtures. Conversely, glycopyrolate matches neostigmine better than atropine. When atropine is given either before or with neostigmine a transient tachycardia is observed. When glycopyrolate is used with neostigmine only small changes in heart rate are seen. Despite these 
combinations, arrhythmias are a common occurrence after reversal of NMBD's. ${ }^{51}$

\section{FACTORS AFFECTING REVERSAL}

1 Extent of spontaneous recovery: The time to full recovery of twitch tension after reversal is dependent upon the residual block present when the anticholinesterase is given. When twitch tension has returned to more than 20 per cent of control, or when train-of-four stimulation demonstrates four visible twitches, the block is easily reversed with doses of neostigmine of $2.5 \mathrm{mg} \cdot 70 \mathrm{~kg}^{-1}$. intense blocks may still be reversible with larger doses of antagonist but total, 100 per cent, blocks may be irreversible. ${ }^{57}$

2 Choice of relaxant: The reversal of equipotent doses of d-tubocurarine or pancuronium at the same degree of recovery is similar whereas gallamine is reversed more slowly and requires a higher dose of neostigmine. The newer relaxants, atracurium and vecuronium have a more rapid rate of spontaneous recovery so that, in some circumstances, neuromuscular activity may have recovered sufficiently to obviate the need for antagonists. If anticholinesterases are necessary recovery can be expected to occur more rapidly than after pancuronium or d-tubocurarine.

3 Choice of antagonist: As already discussed, the rate of reversal of neuromuscular block is more rapid after edrophonium than neostigmine and the rate of recovery after pyridostigmine may be too slow for clinical use.

4 Acid-base and electrolytes: Clinical observations suggest that antagonism of non-depolarizing block is impaired in acidotic states but this has not been substantiated. In acute animal experiments the neostigmine requirement for antagonism of $\mathrm{d}$ tubocurarine and pancuronium is increased by respiratory acidosis and metabolic alkalosis. ${ }^{58}$ Thus, reversal should not be attempted before correction of hypercapnia but the significance of the findings in metabolic alkalosis is uncertain.

Hypokalaemia, hypermagnesaemia and hypocalcaemia are associated with prolonged action and impaired reversal of the non-depolarizing relaxants. However, the roles of intra: extracellular electrolyte concentrations and dehydration in the ill patient have not yet been separated adequately. ${ }^{4}$

5 Pharmacokinetic factors: The antagonism of NMBD's with anticholinesterases can be considered as an acceleration of the rate of spontaneous recovery. Therefore, the slower spontaneous recovery of pancuronium and d-tubocurarine in renal and hepatic failure, as a result of decreased clearance may be associated with slower antagonism of the block. However, the block, when antagonized, produces complete recovery and "recurarization" does not occur ${ }^{59}$ probably because the clearance of anticholinesterases is also decreased in renal failure ${ }^{60}$ In the elderly, decreased renal function reduces the clearances of both relaxants and antagonists so that little change in the antagonism of the block is expected. The pharmacokinetic behaviour of neostigmine in infants and children is similar to adults ${ }^{6.1}$ although the rate of antagonism of relaxants is increased ${ }^{62}$ (Figure 2). These results do not support the belief that infants and children require larger doses of antagonists although it is of utmost importance to ensure full recovery of neuromuscular activity in these patients who may be more vulnerable to the effects of ventilatory failure.

6 Mixed block: When NMBD's are administered in the presence of other substances which also impair neuromuscular conduction such as potent inhalational anaesthetic agents, antibiotics and local anaesthetic agents, the response to the relaxants is potentiated and prolonged. When anticholinesterases are given only the block produced by the NMBD is antagonized. Other methods may reverse the remaining block, e.g., ventilatory elimination of inhalational anaesthetics, or 4-aminopyridine with some antibiotics.

\section{SUCCINYLCHOLINE}

Succinylcholine antagonizes a non-depolarizing block before its own depolarizing block develops. This can be seen when succinylcholine is given either after a pre-curarizing small dose of pancuronium or d-tubocurarine or at the enc of surgery when used to assist peritoneal closure. Care must be taken if succinylcholine is given after administration of anticholinesterases because the latter inhibit plasma cholinesterase and cause prolonged block after succinylcholine. 

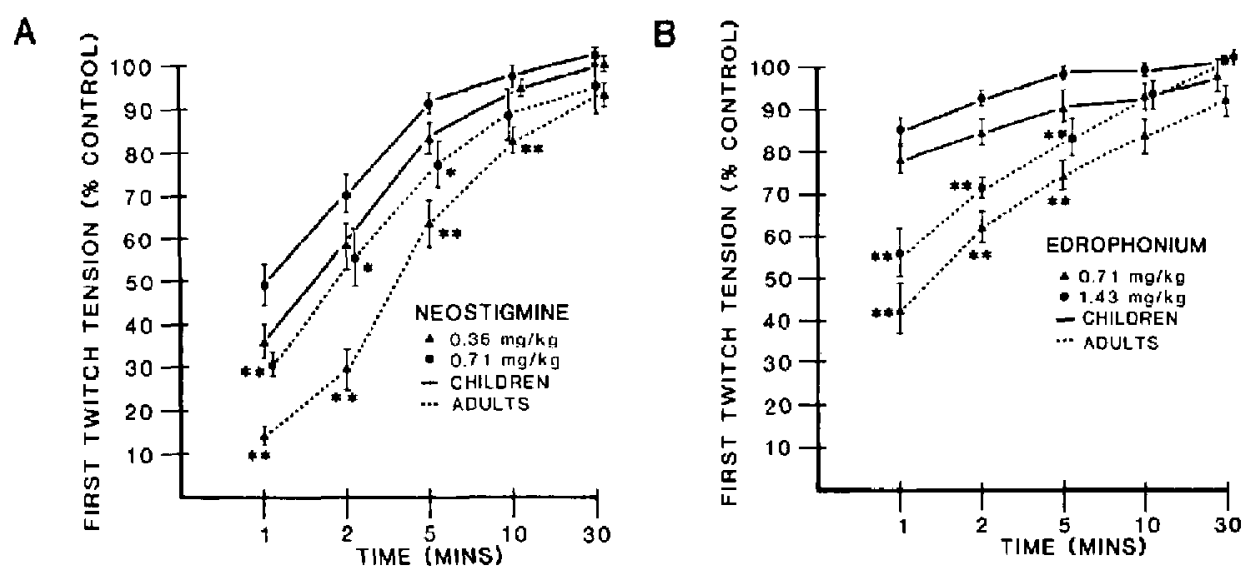

FIGURE 2 Recovery of first twitch tension in paediatric patięnts compared with adults after neostigmine (A) and edrophonium (B). ${ }^{36}$ With permission of Anesthesiology.

When phase II block is fully established, TOF ratio $<0.5$, the block can usually be antagonized with anticholinesterases. ${ }^{63}$ However, the prolonged paralysis associated with abnormal plasma cholinesterase cannot be antagonized despite a trainof-four appearance typical of non-depolarizing relaxants. ${ }^{64}$

\section{CONCLUSIONS}

Whenever NMBD's have been used during anaesthesia attempts should be made to antagonize them if any TOF fade is visible. Reversal may be attempted with an anticholinesterase, either neostigmine $2.5 \mathrm{mg} \cdot 70 \mathrm{~kg}^{-1}$ or edrophonium $35 \mathrm{mg}$ $70 \mathrm{~kg}^{-1}$ mixed with either glycopyrolatc or atropine. The dose may be repcated ten minutes later if recovery of respiration or neuromuscular activity is not complete. However, the choice of antagonists is less important than recognizing indications for their use.

\section{References}

1 Waud $B E$, Waud DR. The relation between tetanic fade and receptor occlusion in the presence of competitive neuromuscular block. Anesthesiology 1971; 35: 456-64.

2 Katz RL. Clinical neuromuscular pharmacology of pancuronium. Anesthesiology 1971; 34: 550-6.

3 Johansen SH, Jorgensen $M$, Molbech S. Effect of tubocurarine on respiratory and non respiratory muscle power in man. J Appl Physiol 1964; 19: 990-4.

4 Miller RD. Antagonism of neuromuscular blockade. Anesthesiology 1976; 44: 318-29.

5 Gal TJ, Goldberg SK. Relationship between respiratory muscle strength and vital capacity during partial curarisation in awake subjects. Anesthesiology 1981; 54: 141-7

6 Ali $H H$, Utting JE, Gray $C$. Stimulus frequency in the detection of neuromuscular block in humans. $\mathrm{Br}$ J Anaesth 1970; 42: 967-78.

7 Lee $C$, Katz RL. Fade of neurally evoked compound electromyngram during neuromuscular block by dtubocurarine. Anesth Analg 1977; 56: 271-5.

8 Ali HH, Savarese J, Lebowitz PW, Ramsay FM. Twitch, tetanus and train-of-four as indices of recovery from non-depolarizing neuromuscular blockade. Anesthesiology 1981; 54: 294-7.

9 Bowman WC. Prejunctional and postjunctional cholinoceptors at the neuromuscular junction. Anesth Analg 1980; 59: 935-43.

10 Sranec A, Stanec $G$. The adductor pollicis monitor - apparatus and method for the quantitative measurement of the isometric contraction of the adductar pollicis muscle. Anesth Analg 1983; 62: $602-5$.

11 Epstein RA, Epstein RM. Electromyography in evaluation of the response to muscle rclaxants. $I n$ : 
Muscle Relaxants (ed. Katz RL), Excerpta Medica, New York, 299-312 (1975).

12 Lam HS, Morgan DL, Lampard DG. Derivation of reliable electromyograms and their relation to tension in mammalian skeletal muscles during synchronous stimulation. Electroenceph Clin Neurophys 1979; 46: 72-80.

13 Viby-Morgensen J. Clinical assessment of neuromuscular transmisșion. Br J Anaesth 1982; 54: 209-23.

14 Waud BE, Waud DR. The margin of safety of neuromuscular transmission in the muscle of the diaphragm. Anesthesiology 1972; 37: 417-22.

15 Cullen SC. The use of curare for the improvement of abdominal muscle relaxation during inhalation anaesthesia. Surgery 1943; 14:261-6.

16 Rees GJ. Paediatric anaesthesia. Br J Anaesth 1960; 32: $132-40$.

17 Kelly. SS. Robers DV. The effect of age on the safety factor in neuromuscular transmission in the isolated diaphragm of the rat. $\mathrm{Br} J$ Anaesth 1977; 49: 217-22.

18 Keens $T G$, Bryan AC, Levison $H_{1}$ Ianuzzo $C D$ Developmental pattern of muscle fiber types in human ventilatory muscles. J Appl Physiol 1978; 44: 909-13.

19 Goudsouzian NG, Crone $R K$, Todres $I D$. Recovery from pancuronium blockade in the neonate intensive care unit. Br J Anaesth 1981; 53: 1303-9.

20 Crumrine RS, Yodlowski EH. Assessment of neuromuscular function in infants. Anesthesiology 1981; 54: 29-32.

21 Nightingale DA, Glass AG, Bachman L. Neuromuscular blockade by succinylcholine in children. Aresthesiology 1966; 27: 736-41.

22 Walts $L F$, Dillon JB. The response of newborns to succinylcholine and d-tubocurarine. Anesthesiology 1969; 31: 35-8.

23 Cook $D R$, Fischer $C G$. Neuromuscular blocking effects of succinylcholine in infants and children. Anesthesiology 1975; 42: 662-5.

24 Waits $L F$, Dillon $J B$. Clinical studies on succinylcholine chloride. Anesthesiology 1967; 38: 372-6

25 Katz $R L, R y a n J F$. The neuromuscular effects of suxamethonium in man. Br J Anaesth 1969; 41: 381-90.

26 Cook DR, Fischer CG. Characteristics of succinylcholine neuromuscular blockade in neonates. Anesth Analg 1978; 57: 63-6.
27 Sutherland GA, Bevan JC, Bevan DR. Neuromuscular blockade in infants following intramuscular succinylcholine in two or five per cent concentration. Can Araesth Soc J 1983; 30: 342-6.

28 Liu LMP, De Cook TH, Goudsouzian NG, Ryan JF, Lik $P L$. Dose response to intramuscular succinylcholine in children. Anesthesiology 1981; 55: 599 602.

29 Zsigmond EK, Downs JR. Plasma cholinesterase activity in newborns and infants. Can Anaesth Soc J 1971; 18: 278-85.

30 Cook DR, Westman HR, Rosenfeld L. Hendershot $R J$. Pulmonary edema in infants: possible association with intramuscular succinylcholine. Anesth Analg 1981; 60; 220-3.

31 De Cook TH, Goudsouzian NG. Tachyphylaxis and phase II block dewelopment during infusion of succinylcholine in children. Ancsth Analg 1980; 59: $639-43$.

32 Goudsouzian NG, Liu LMP. The development of tachyphylaxis and phase II block during the infusion of succinylcholine in infants. Anesthesiology 1983; 57: A284.

33 Basta SJ, Ali HH, Savarese JJ et al. Clinical pharmacology of atracurium besylate (BW 33A): a new non-depolarizing muscle relaxant. Anesth Analg 1982; 61: 723-9.

34 Goudsouzian NG, Liu LPM, Cote CJ, Gionfriddo $M$, Rudd $G D$. Safety and efficacy of atracurium in adolescents and children anesthetized with halothane. Anesthesiolagy 1983; 59: 459-62.

35 Goudsouzian NG. Liu LMP, Gionfriddo M, Otcasek $D$. The dose response effect of atracurium in infants. Anesth Analg 1984; 63: 223.

36 Fahey MR, Morris RB, Miller RD, Soln YJ, Cronelly $R$, Gencarelli $P$. Clinical pharmacology of ORG NC45 (Norcuron). A new nondepolarizing muscle relaxant. Anesthesiology 1981; 55: 6-11.

37 Fisher DM, Miller RD. Neuromuscular effects of vecuronium (ORG NC45) in infants and children during $\mathrm{N}_{2} \mathrm{O}$, halothane anesthesia. Anesthesiology 1983; 58: 519-23.

38 Goudsouzian NG, Ryan JF, Savarese $J J$. The neuromuscular effects of pancuronium in infants and children. Anesthesiology 1974; 41: 95-8.

39 Donlon $J V$, Ali $H H$, Savarese $J I$. A new apprnach to the study of four non-depolarizing relaxants in man. Anesth Analg 1974; 53: 934-8.

40 Goudsouzian NG, Donion JV, Savarese JJ, Ryan 
$J F$. Reevaluation of dosage and duration of action of $d$-tubocurarine in the pediatric age group. Anesthesiology $1975 ; 43: 416-25$.

41 Goudsouzian NG, Liu LMP, Savarese JJ. Metocurine in infants and children. Anesthesiology 1978; 49: $266-9$.

42 Goudsouzian NG, Liu LMP, Cote CJ. Comparison of equipotent doses of non-depolarizing muscle relaxants in children. Anesth Analg 1981; 60 862-6.

43 Savarese JJ, Ali HH, Antonio RP. The clinical pharmacology of metocurine. Ancsthesiology 1977; 47: $277-84$.

44 Fisher DM, O'Keeffe C, Stanski DR, Cronnelly $R$, Miller RD, Gregory GA. Pharmacokinetics and pharmacodynamics of d-tubocurarine in infants, children and adults. Anesthesiology 1982; 57 203-8.

45 Churchill-Davidson HC. The d-tubocurarine dilemma. Anesthesiology 1965: 26: 132-3.

46. Ali HH, Wilson RS, Savarese IJ, Kitz RJ. The effect of tubocurarine on indirectly elicited train-offour response and respiratory measurements in humans. Br J Anaesth 1975; 47: 570-4

47 Bevan DR. Reversal of pancuronium with edrophonium. Anaesthesia 1979; 34: 614-9.

$48 K o p m a n A F$. Edrophonium antagonism of pancuronium-induced neuromuscular blockade in man: a reappraisal. Anesthesiology 1979; 51: $139-42$.

49 Ferguson A, Egerszegi P, Bevan DR. Neostigmine, pyridostigmine, and edrophonium as antagonists of pancuronium. Anesthesiology 1980; 53: 390-4.

50 Cronnelly $R$, Morris RB, Miller RD. Edrophonium: duration of action and atropine requirement in humans during halothanc anesthesia. Anesthesiology 1982; 57: 261-6.

51 Morris $R B$, Cronnelly $R$, Miller RD, Stanski $D R$, Fahey $M R$. Pharmacokinetics of cdrophonium and neostigmine when antagonizing $d$-tubocurarine neuromuscular blockade in man. Anesthesiology 198 1; 54: 399-402.

52 Randall LO, Conroy CE, Ferruggia TM, Kappell $B Y H$, Knoepel CR. Pharmacology of the anticholinesterase drugs - mestinon, prostigmin, tensilon and TEPP. Amer J Med 1955; 19: 673-8.

53 Miller $R D$, Cronnelly $R$. A new look at an old drug. Anesthesiology, 1983; 59: 84-5.

54 Sugai N, Payne JP. The skeletal muscle response to edrophonium during neuromuscular blockade by tubocurarine in anacsthetized man. Br J Anaesth 1975; 47: 1087-92.

55 Payne JP, Hughes $R$, Al Azawi S. Neuromuscular blockade by neastigmine in anaesthetized man. $\mathrm{Br} \mathbf{J}$ Anaesth 1980; 52: 69-76.

56 Azar I, Pham AN, Karambelkar DJ, Lear E. The heart rate following edrophonium-atropine and edrophonium-glycopyrollate mixtures. Anesthesiology 1983; 59: 139-41.

57 Lee $C$, Karz RL. Neuromuscular pharmacology: a clinical update and commentary. Br J Anaesth 1980; 52: $173-88$.

58 Miller RD, Roderick LL. Acid-base balance and neostigmine antagonism of pancuronium neuromuscular blockade. $\mathrm{Br} J$ Anaesth 1978; 50: 317-24.

59 Bevan DR, Archer D, Donati F, Ferguson A, Higgs $B D$. Reversal of pancuronium in renal failure. $\mathrm{Br} \mathbf{J}$ Anaesth 1982; 54: 63-8.

60 Cronnelly $R$, Stanski $D R$, Miller $R D$, Sheiner $L B$, Sohn YJ. Renal function and the pharmacokinetics of neostigmine in anaesthetized man. Anesthesiology $1979 ; 515: 222-6$.

61 Fisher DM, Cronnelly $R$, Milier RD, Sharma $M$. The neuromuscular pharmacology of neostigmine in infants and children. Anesthesiology 1983; 59 : 220-5.

62 Meakin $G$, Sweet PT, Bevan JC, Bevan DR. Neostigmine and edrophonium as antagonists of pancuronium in infants and children. Aresthesiology 1983; 59: 316-21.

63 Futter ME, Donati F, Bevan DR. Neostigmine antagonism of succinylcholine phase Il block: a comparison with pancuronium. Can Anaesth Soc $J$ $1983 ; 30: 575-80$.

64 Bevan $D R$, Donati $F$. Succinylcholine apnoea: attempted reversal of anticholinesterases. Can Anaesth Soc 1 1983; 30: 536-9. 